\title{
Transatlantica
}

Revue d'études américaines. American Studies Journal

\section{'The Artist Himself Is a Kind of Idiot.' An Interview With Jerome Charyn}

Michaëla Cogan

\section{(2) OpenEdition}

Journals

Electronic version

URL: https://journals.openedition.org/transatlantica/16171

DOI: $10.4000 /$ transatlantica.16171

ISSN: 1765-2766

\section{Publisher}

Association française d'Etudes Américaines (AFEA)

Electronic reference

Michaëla Cogan, "The Artist Himself Is a Kind of Idiot.' An Interview With Jerome Charyn",

Transatlantica [Online], 2 | 2020, Online since 10 March 2021, connection on 21 February 2023. URL: http://journals.openedition.org/transatlantica/16171 ; DOI: https://doi.org/10.4000/transatlantica. 16171

This text was automatically generated on 21 February 2023.

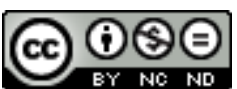

Creative Commons - Attribution-NonCommercial-NoDerivatives 4.0 International - CC BY-NC-ND 4.0 https://creativecommons.org/licenses/by-nc-nd/4.0/ 


\section{'The Artist Himself Is a Kind of Idiot.' An Interview With Jerome Charyn}

\section{Michaëla Cogan}

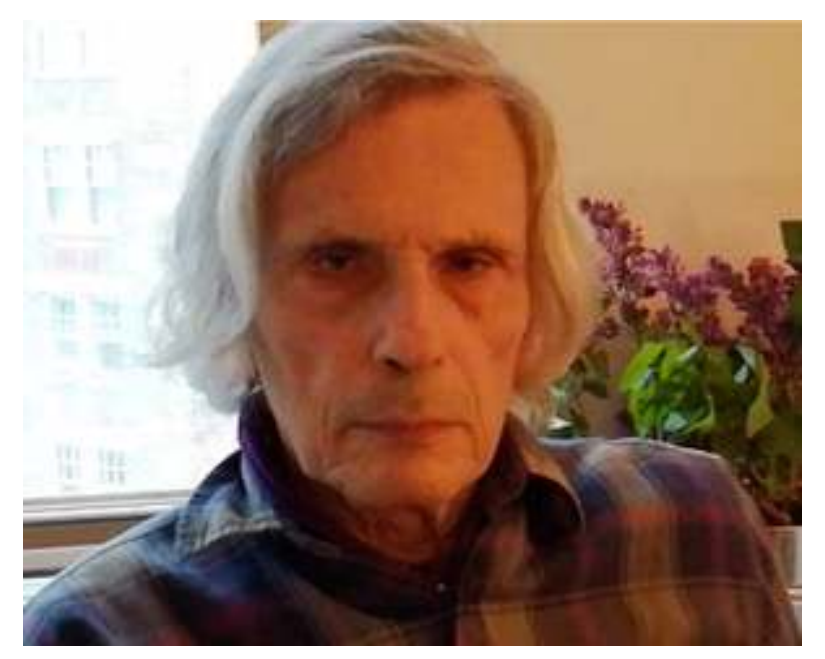

熙 Michaela Cogan. Jerome Charyn in 2017.

1 Born in the Bronx in 1937, Jerome Charyn published 'Faigele, the Idiotke,' his first short story, in Commentary in 1963. After a series of experimental novels, culminating in Eisenhower, My Eisenhower ${ }^{1}$ in 1971, he happened upon the writing of mysteries with his 1974 Blue Eyes ${ }^{2}$, an immediate success paving the way for the twelve-volume Isaac Sidel saga. He has published a number of historical novels and biographies, the latest of which Sergeant Salinger ${ }^{3}$ (2021), and has developed a vibrant autofictional streak in several memoirs set in the Bronx where his mother, father and brother act as reinvented figures. Several non fictional works on American culture and New York have made him a scholar in those fields, and he has also collaborated with various illustrators on graphic novels, for instance François Boucq in New York Cannibals ${ }^{4}$ (2020). He now lives in New York. 
2 Jerome Charyn kindly granted me the time to interview him at his home in April 2017. Our conversation started on the omnipresent theme of idiocy in his work, and then drifted towards many other subjects.

MICHAËLA COgAN: I'm presently working on clarifying the function of the motif of the idiot in your fiction-what those figures mean, how they could be interpreted, what they reveal, perhaps, about a particular vision of the world. I'm currently trying to classify those representations, to sort them into different "types" of idiots. Could you give me your own definition, your vision, how you perceive the figure of the idiot-you told me the subject was of interest to you?

Jerome Charyn: The word "idiot" is a difficult word because it has so many connotations. In French, you can modulate it in many, many ways. The first story I wrote, "Faigele the Idiotke," was about an idiot girl. I would say that mental instability is very important to art itself, because if you were absolutely sane, you would go along a very regular path and you wouldn't be able to move quickly from side to side. So it starts with the writer or the artist himself, who is a kind of idiot. And I think it's Flaubert who defined his own art as a kind of idiocy.

Anyway, I would say that it starts with a certain sympathy, a certain empathy because remember, you are using language and talking about people who don't have any sense of language or have a very distorted sense of language. So, for me, there is an immediate empathy and also, I never really write about the "quotidian" or middleclass people with families. I would say that the sympathy was there from the very beginning because I came from a culture where people had no language, so the idea of people living without language or living in the turmoil of their head was very important to me. The Sound and the Fury was also a very important novel to me, with the character of Benjy. Dostoievsky also, not only the novel The Idiot but his whole work which is full of idiot figures.

I just did a novel on Jerzy Kosinsky ${ }^{5}$. The boy in Jerzy Kosinsky's novel ${ }^{6}$ meets this woman who is a kind of idiot-Ludmila, I think her name was. The idiots are everywhere. In the novel Pinocchio's Nose ${ }^{7}$, you can consider Pinocchio, the wooden boy, as a kind of idiot because as a wooden boy he has no language. It all depends on how you want to define the idiot because it's such a large topic, it's such a difficult topic. And also in my crime novels there is the Baby, the Guzmann boy who is also an idiot: Jerónimo, which to me is my name, so he's also a mirror of me, in some way.

MC: In an interview with Frederic Tuten, you said: "I've always felt incredible sympathy for the figure of the idiot because he's a kind of genius. You think of people like Einstein, misfits who just happened to have a particular flash of genius 8." Isn't there a sort of paradox between the idiot who has no language and the genius who is, in a way, in command of language, or at least of his own means of expression?

JC: Yes, look at Einstein, who had really not that much formal training. He was a clerk, and all his professors in the University were working out these theories, and he was the one who was able to work it out in his head. So there is a kind of relationship between the inability to express and the explosion of art when suddenly the expression comes as a kind of music that you have and that you lose. Normalcy is always along a straight line. The idiocy is always the curve, the root that you cannot locate, that you cannot find. And I would also define that greatness in art-and I'm not only talking about my art, but about any art-is how close you can come to chaos 
without it turning into chaos. To me the greatest works of art are always at the edge, at the borderline of chaos, because that's where music really exists.

MC: In the beginning, the idiot is the one who is not normal, who exists outside, in the margins.

JC: Yes, he has a vision, he's a visionary. He doesn't see the normal way. He or she does not have the normal progression from childhood to adulthood to marriage, to having children, to death. In a way, the idiot remains a child.

MC: The figure of the child, the frozen child stuck or paralyzed in childhood is salient in your work. One of your earlier stories is entitled "The Man Who Grew Younger ${ }^{9 "}$.

JC: Yes, and also Günter Grass's Tin Drum is very important. The boy stops growing during the war, and remains a child with his drum. A very powerful image to me, very important. I never liked anything else he wrote, but that book was wonderful.

MC: If the idiot doesn't move, he's also the only one who doesn't change, who represents some sort of perennial truth, or perhaps who is able to live in the present?

JC: Truth you have to be careful of, because we don't know what that word means. But he remains-or she, because you know, Faigele the Idiotke is a girl-remains true to his or her own passion, I would say.

MC: Faigele was your mother's nickname as well...

JC: Faigele was my mother's name. She was called Faigele.

MC: Why the character of "Faigele the Idiotke," why this name?

JC: Well, it was a way of-it was a name that I knew, and also Faigele means little bird. So you see, she tries to fly.

MC: She also speaks with birds.

JC: Yes, so she is kind of a bird. And that's the first story. The first thing that you do always leaves its own mark on you. You have this young man who wants to become an artist and leaves his home to go to the Lower East Side, which is really where I came from because that's where all the Jews, or most of them, landed from Europe. And you have this tale about this girl who wants to fly. I don't know, but to fly is to move into language itself, to move into the impossible. And this is what any work of art is, the dream of going into impossibility, it seems to me, which we never accomplish.

MC: You were talking about ambition. If we compare Manny to Faigele, Faigele has no real purpose, no visible aim in life. Jerónimo, too, is in a way paralyzed, static, and he doesn't really evolve as a character.

JC: No, but he has his own secret world of redressing these young boys and then killing them. He does have a purpose but we don't understand what that purpose means, we're not able to enter into what he's negotiating, we don't understand.

MC: So there's no emptiness really, no real silence. I thought the idiot figures might embody some kind of void, but no.

JC: No, it's a kind of silent music. I don't think... In terms of traditional silence, Jerónimo doesn't, can't speak, and Faigele can't speak, but they have music, they do have music.

MC: Faigele does speak, but not with words.

JC: She has a music, she has a grace, that we don't have. The boy, the painter, who has no talent but wants to go, to be Portrait of the Artist as a Young Man, so he leaves his 
home, goes down to the Lower East Side, just before the war, so that he can be an artist, and what does it mean?

MC: So she is the character who personifies the artist, not Manny, the main protagonist and the narrator, who wants to become a painter but may end up joining the army.

JC: Of course. He uses the term "artist," but he's not an artist. And I always think of Rothko, the painter, sitting in his studio and freezing, after he was a multi-multi millionaire, because (chuckles) he couldn't seem to buy an overcoat. You see, we're always stuck in some kind of paralysis. He couldn't-he had millions! And also, when Samuel Beckett broke up with his wife and didn't know what to do, his publishers said, "Well Sam, you have millions in your account, you could buy a whole building!" And he wasn't capable of doing it, he went into an old-age home. He wasn't capable of living a practical life. When I was in Paris I would see him very often going down to the Boulevard Raspail just by the cemetery and walking like this, he was so drunk, it was 11 o'clock in the morning, he was so drunk he couldn't even walk a straight line! Beckett didn't have the psychic space in his head. I don't think he even ever asked the publisher for royalties, probably the publisher sent him money to live. Remember this is the time when he won the Nobel Prize, so he had a lot a money, but it wasn't real to him. Anyway he's someone I really respect because the writing, like Waiting for Godot, to me is really... I do like some of Pinter, The Homecoming I really liked, that's the one playwright. After seeing Waiting For Godot, so stripped and so bare... it's very hard for me to think of theatre beyond that play. Where does one go, I really don't know.

\section{MC: Beckett had a particular relationship with silence, didn't he?}

JC: Yes, and also the fact that he was James Joyce's assistant is wonderful because the most musical writer of all writers ever was perhaps Shakespeare, but in our own time, it would be James Joyce. Beckett was Joyce's assistant, and his whole work is about silence-in the end, he ends up with plays where there's no words, there's no language!

MC: Which is not your case at all-

JC: I think it is my case, but it's a different way of going. I'm not comparing myself to Samuel Beckett. We all end up with silence anyway, no matter how much we sing or whatever.

MC: But silence within language is different than complete silence.

JC: Yes, because you're talking about Beckett but I was just making a comparison between being Joyce's assistant and wanting to write like Joyce. He's the writer who's the least like James Joyce. He's not funny, well he is funny but Joyce had a kind of warmth that Beckett just didn't have, that he wasn't interested in.

MC: I would like to come back to Faulkner's The Sound and the Fury. You have often said that Benjy's song was very influential in the development of your voice. His inability to express himself made you think of your father, and your characters started reflecting this lack of language. In your own words, you started "manufacturing idiot boys, dropping Benjy into everything [you] wrote ${ }^{10 . " ~ N o w, ~ i f ~ w e ~ t a k e ~ M e l v i l l e ' s ~ B i l l y ~ B u d d, ~ w o u l d ~ y o u ~ c o n s i d e r ~ h i m ~}$ an inspiration as well?

JC: Melville's Billy Budd or Bartleby. Bartleby is another example: "I would prefer not to," the idea that he's a scribe, a scrivener who doesn't write! Melville is also so much about silence. Even though he wrote so many novels, he fell into complete silence. What is the audience in anything you write? Where is the audience and what is the 
audience? To me, you are both the writer and the audience at the same time. Of course, you want to give other people pleasure in reading what you write but basically you are writing songs for yourself. Maybe other writers wouldn't say that. No one else is going to understand what you have to say, the relationship between the words, they're not going to be able to see why this sentence leads into that sentence. They just don't have the visualization. I would think the same thing of Picasso: who can really understand Picasso other than Picasso?

MC: So there is an inner coherence to the text.

JC: There has to be an inner music and I don't think it's accessible. It's also a closed key. Now on the other hand, it has to be accesssible because it has to make sense to other people in some way, but in another way it is a very closed key, a closed world.

MC: It seems that you're describing writing, and your own depiction of the idiot figure, as something personal, intimate. But the filiation with Faulkner or Melville is also salient. How would you situate yourself with regards to those writers?

JC: Those are writers that I admire. I can't say which of the writers you resemble. You can only talk about what you love. I love Emily Dickinson. I particularly love the fragments that she wrote near the end of her life. And again there's a critic who wrote about what she calls "radical scatters," the movement away from the center into the edges. A scattering of words. This is what finally the song is about. For most people, it's not what they want. Most people want to cohere, so what I write is not going to be visible to most people because they are searching for a mirror of themselves and their own vanity sees a kind of coherence which I don't believe exists. It takes a very particular kind of reader, maybe someone like yourself, who would be interested in this work.

MC: You're talking about a scattering, which is also a form of going to the edges of chaos without falling into chaos.

JC: Oh, we don't know, maybe the chaos is more beautiful than the movement towards chaos. But then I wouldn't be able to understand what I wrote! What's most important is that when you write something, you understand. You have to understand, as a writer, reader.

MC: It has to have minimal structure.

JC: It has to cohere in some way, it has to make sense. But I'm always startled, certain books have an absolute music and in other books, the music is lacking. And you begin to wonder why-did something go wrong? Darlin' Bill ${ }^{11}$ is very musical for me, it's like a song from the beginning to the very end. I wrote much of that when I was teaching in Princeton, and I wrote much of it on the train going out to Princeton. When you have the music, the music doesn't leave you.

MC: Lacan emphasizes the father figure and the law as a structuring principle. In your fiction the fathers are often missing, or inadequate.

JC: And also they're evil, not really fathers because they don't give you-like in the Sistin Chapel, God's hand sticking out to lead. The father is absent, so that's why you have idiots: without a father, you can't grow up. 
MC: You say that Sam, your father, had trouble with language. This comes as a consequence of his situation as an immigrant to a country whose language he could neither understand nor speak.

JC: The work he did as a furrier was very good but he really wasn't able to fathom the world. I remember once, I was nine or ten years old and he thought throughout his life he had ulcers, and I would take him to this doctor and he didn't have any ulcers at all. Constantly afraid. This is your father who's very cruel, does terrible things and is also weak at the same time. It's the worst combination for a child. If you have a father who's mean, that's one thing, but a father who's mean and weak at the same time, that's not good. But I had my brother, thank God, he did look after me.

MC: The fatherless child seems to be helpless; he has no tools to apprehend the world.

JC: But the child does have an imagination, see, so the child has an internal coherence even though the child cannot negotiate, just as Faigele the Idiotke can't negociate the world. She's going to jump off the roof and end up in a kind of eternity. She doesn't have the ability to negotiate or to understand what this world is about.

MC: Children have their own creativity. You describe yourself as a peculiar child who didn't cry, didn't express his wants.

JC: No, I didn't cry, my mother said I never cried. I had an older brother who cried all the time and she said it was so startling to her because I didn't cry, she didn't quite understand. My father was very jealous. His absence was that he was present, but not as a father; he was present as someone who felt that his own son was a kind of intruder. What does it mean for a child to look at his father's face and not see any love at all, just menace? It's a very disturbing thing. How do you stay sane under those circumstances? It's not so easy.

MC: You discovered language through comics, and the movies-

JC: And also my brother, my brother was very important to me because he did love me and it was very clear that he did love me. I did have a kind of father-brother to lead me in some way into adulthood. He was three years older, so I did what he did when he started lifting weights. I was lifting weights at twelve.

MC: In The Catfish Man'2, Jerome is fascinated by his brother Harvey's body and physical strength. But in the end Jerome chooses his own direction with words.

JC: It was very boring after a while. I couldn't paint, I wanted to become an artist but I didn't have talent, I was at the high school of Music and Art where other people did have talent and you could see the genius that they had. I couldn't describe, other people can negotiate the world through an image. The only image I could do was through words and even that was not so easy. But at least I felt the words were there, so maybe I had a chance to use them in the right way.

MC: Somewhat like Imberman, in the eponymous short story, who goes from weightlifting to writing poetry.

JC: Yes, but he doesn't end up in a very good way. The actual person that I based that story on was a weightlifter. For a boy, heroes were to be found in Mister America. I read them all and had all the magazines. The actual character's name was Al Berman and he got involved with drugs. He was someone I admired. He had a younger brother whom I knew. One day, I was teaching as a substitute teacher during the summer in high school, and there he was in my school, he had lost all of his muscles! Your hero 
suddenly becomes very very feeble, he wanted to write. I think I told him that I knew who he was. It was very strange, how people fall from grace, how easy it is to fall.

MC: How does physical strength fascinate you? People with strong bodies are often described, in your writing, as also inept or inarticulate, although there are exceptions, if you take Esther Madrid in Croc du Serpent ${ }^{13}$ for instance. For example, Joe DiMaggio ${ }^{14}$ is talented on the field but not in his own life.

JC: Yes, he has no language other than the language of his body, and also in the baseball novel, The Seventh Babe $e^{15}$, you have an impossible situation. You have a third base who's left-handed. You're throwing the first base so you're going to be two or three seconds behind if you're left-handed. But I insisted on having a left-handed third-base man. It's a book about an impossibility. There's never been a left-handed third-base man. You can be ambidextrous and be left-handed but you're going to throw with your right hand. Impossibility is always the beginning of everything. Anything that's possible is not really interesting.

MC: In Sizzling Chops ${ }^{16}$, you develop the idea of how being left-handed has changed the way that you could live in the world.

JC: I felt very different. Sometimes I couldn't even get out of a toilet because I couldn't move the lock. I couldn't negotiate. Not only was I “débile” in many ways, but because I was left-handed I was very different. Of course it was an advantage in table tennis, when you play someone for the first time. I played in many tournaments, for a while I think I played ping-pong and didn't write. The problem for most people is that they couldn't play left-handed people. They were trained right-handed to righthanded. I always played right-handed people, so if I ever played a left-handed person, it was very difficult for me. For me, being a little bit of an idiot was a benefit in table tennis.

MC: Looking at some of the names of your characters-Manny, Imberman, Catfish Man, Paradise Man, we may have the impression that for you it is all about growing into a fullfledged man, about becoming autonomous as a human being.

JC: Well. Man is a disguise for a boy, the boy who pretends to be a man. In many of the titles they're not really men, they're boys. It's just the name, what does it mean?

MC: What about superheroes?

JC: Superman, Batman, Captain Marvel. I liked the drawings in Captain Marvel, I loved the art. Comic books were very important to me and still are.

MC: You often talk about the golem. Is the golem a figure that you found in the comics?

JC: No, the golem to me was important because again, the golem is a kind of child who is both powerful and weak at the same time. And also the golem has no voice.

MC: He's powerful physically but isn't able to express himself.

JC: He has no language.

MC: He's a mute figure, and yet you give him a voice, as a golem writer...

JC: It comes out of silence, it comes out of the brutality of one's childhood. Yes, I do feel like a golem. Of course I don't go around murdering people, and nor do I want to. It's the idea that the golem is a kind of Frankenstein. And also the fact that in a world where Jews were persecuted, the golem was a kind of great police who was going to attack the attackers. So I liked the idea. Physical power is very important to me. I don't have it but I like it, I like to see it. 
MC: The golem is also linked to raw matter, a kind of mud that is transformed.

JC: A kind of shit, of mud, clay, dirt, transformed into-into language in a sense. Where does language come from? It's always a mystery to me. Why should certain people have the gift of language and other people don't? I don't really know.

MC: You also use the word « geek».

JC: Geek. Geek comes from a film, Nightmare Alley ${ }^{17}$. In other words, the geek in a show is someone who has lost all self-respect and he ends up in a corner of an act swallowing live chickens.

MC: Why? In a way the geek ingests things that other people reject. Why swallowing? In a way he relates to the outside world by devouring what is not digestible.

JC: He does what no one else would do. He's a geek. To me it was a perfect kind of character to write about. Nightmare Alley was a film that I really liked.

MC: When people go to the movies, they also swallow the images, they cannot sort them out, you are swallowed up by the screen. That's the impression I have.

JC: No, not for me. I think it's Joyce Carol Oates who explained it to me. I must have some kind of ability to visualize because, and this is not a joke-let's say, there was an actor by the name of Joseph Wiseman who played minor roles in a few films, one with Marlon Brando ${ }^{18}$. And about thirty years later I saw the back of his head in the street and I knew it was him. Just by the back of his head! In other words, the brain was able to-maybe swallow is not the right world, maybe digest, ok, to visualize. I can see someone as a child and see them grown-up and know that it's the same actor. Somehow I can visualize, maybe it's a curse and maybe it's a gift.

MC: Your writing is also able to translate the visual.

JC: It is. That's one reason why we're going to turn the crime novels into an animated series because the writing is visual. When I would describe something, I would visualize it. A fan on the floor looked like a kind of dinosaur. Joe Staton ${ }^{19}$ was able to visualize my vision. And also the writing scripts for graphic novels: it gives me a great deal of pleasure because I can visualize it in my own head, I can imagine the art, you see, because I'm not an artist. I remember for example when I worked in a television pilot and I wrote some words and when I saw them on the screen, I heard the actors pronounce them and we looked at the rushes, I thought I would be fascinated, I thought I would be elated by hearing my own words. I wasn't. I was very distressed, it didn't give me any pleasure whatsoever. They weren't mine. Even though I'd written them, they weren't mine. But when I do a graphic novel, I write the image and the artist translates it into an image, I don't feel that I cannibalize the artist, but I feel the personal connection between what I wrote and what he or she drew on the page, so that's very important to me.

MC: Could we come back to the character Jerónimo Guzmann, this recurrent character in the Isaac Sidel series that you briefly mentioned a while ago? Is he a variation on your own name?

JC: And Jerónimo the Indian chief too.

MC: Yes. You say in the Bronx trilogy that your hair became gray early, just like Jerónimo's, the retarded boy, whose hair grows prematurely grey. Even though in the Sidel series he's not really important for the plot, he comes and goes and the protagonists keep looking for him. They have a recurring question, "Where is Jerónimo?".

JC: He's called the Baby, which is what I was called as a child. 
MC: You say he's a mirror of yourself. Did you build him up as a self-portrait, in the manner of Renaissance painters who would lend their features to one of the people on the canvas, often in a grotesque way?

JC: Yes, Michelangelo was a hunchback. You know, there is no one-to-one relationship between... Ok, when you do a plot, you have to be conscious of what you want to do. But when you write the sentences, you write as if you're in a dream, so you're not exactly sure of how it's going to come out. So if you ask me what the importance of Jerónimo is-first of all he's very strong, and he's also a murderer and he has to be taken care of, like a baby, like a child. And he has this wonderful name. I remember I was in a drug store yesterday and the woman who gave me the prescription-she was a Latina woman-said, “Ah, Jerónimo, it's a very beautiful name!"

MC: He's violent because he kills little boys and also paints their mouths...

JC: ... with lipstick, the Lipstick freak.

MC: As he himself cannot speak, his violence is a form of language in a way.

JC: It's a scream, it's a language and also the painting of the lips is a kind of, it's the way he probably makes love. He turns them into women by giving them lipstick.

MC: I thought he was giving them a voice...

JC: Yes, it could be. Remember it's not always clear to the person writing what any of these things mean. I can only describe the image of what I wrote. But to me the lipstick is very sexual. You're taking a doll and you're animating it. Then it becomes violent so that it's also a kind of orgasm.

MC: In a way, there's the idea of a raw energy that needs to be channeled. Jerónimo, who has no language, is driven by this superfluous brutal energy, but he has no access to language, which would have been a way for him to turn this energy into something. So he's violent instead.

JC: Yes, this is the way he speaks. But you see it's not different from art, which is also brutal. Even the movement into words from the blank page is a brutal kind of gesture. Language itself is brutal. I always felt that.

MC: Still, what is his function in this novel? In the end, he's identified as the murderer, but before that, he isn't really the object of attention, he is almost a parasite, a marginal character. Although, in the end, he is the one that everyone-or the police, at least-is looking for.

JC: Yes, but in The Education of Patrick Silver ${ }^{20}$, Patrick Silver takes him to the Plazza Hotel and also he's sacred, he's a kind of saintly person, he has to be taken care of.

MC: The Christian tradition values the meek and simple-minded as sacred people. Dostoevsky's Myshkin probably participates in this vision. The Jewish culture, in contrast, seems to value the idiot from a different perspective-Singer's "Gimpel the Fool" and fools of Chelm, the schlemiel, or even Moses, who has a stammer...

JC: Yes, an impairment. But you don't have the same sense of charity. In a strange way, the Hebrew Bible is very moral but also very cruel, very, very cruel.

MC: In the first volume of the Isaac Sidel saga ${ }^{21}$, is Manfred Coen an innocent?

JC: Well, I would say he's a little bit stupid.

MC: He looks like Billy Budd.

JC: He's blond with blue eyes, sort of Isaac's golem because he's very violent at the same time, called Shotgun Coen with his shotgun in a shopping bag. I was thinking of 
my brother when I wrote that book. Again, what you do is very personal and how is the reader ever going to know what the genesis, the source of that book is? Even if you researched it for three thousand years, you wouldn't be able to find the clues that are, or let's say, what's driving me because I'm not totally aware of it myself, and yet it has to make sense. And I don't know, that's a book that many people have liked and I never understood why they liked that particular book. I don't really know.

MC: Isaac Sidel is supposed to bring back harmony into a chaotic world, but his techniques are not always legal. He uses his own code of honor, his own intuition, adding to the chaos.

JC: Yes, I see him as a kind of Don Quixote. He's living in a world that's imperfect and yet he wants to make changes that are never going to be possible, so when he becomes president in the twelfth book, he wants to sort of fund free lunches for everyone and all the advisors around say, "you can't do that, you can't do that, it won't work-these are not the people that elected you." So he's trapped in what you call the White Jail. The most destructive thing he ever did was sort of provoke Manfred Coen's death and he paid a tremendous prize for it, which is the tapeworm. He's a kind of-in this book I call him Don Quixote with a Glock. He shoots people.

MC: In The Sound and the Fury, one reason given for Benjy's idiocy is consanguinity and the degeneration of the Compson family. But in the Guzmann clan, all the boys have different mothers, and family is seen as a very heterogeneous reality, implying a variety of distant relatives, religious rituals and languages. While Benjy's idiocy seems to stem from an excess of sameness, would Jerónimo's idiocy originate in hybridity?

JC: They're all foreign, they're all strange, they're Marranos, they're secret Jews. They have their own rituals, they're thieves and pimps. What I like best is that they work out of a candy store. Now, when there were other writers working on this project, they changed the candy store into a bodega and I was thinking, "My God, you have to be so fucking stupid, how can you do a drawing of a bodega that's going to be as interesting as a drawing of a candy store with all this candy?" In the pilot, it was a bodega.

I don't know where his idiocy comes from. His idiocy is my idiocy. Where do I come from? I mean, I was the first one in my family to go to college. Where did this gift, or this interest... never mind gift because you never know what gift you have. Nobody, no one is going to be able to, can really determine the quality of anyone's work. Maybe in two hundred years, people will be able to tell what's good. To me, whether you like The Great Gatsby or not, it tells you something about the 1920's that no other book does because he lived through it. Somehow he was able, in this very strange character of Gatsby, to tell you what the 1920's was about so it's difficult for me to-I know what I like and what I don't like, but I wouldn't be able to describe what makes sense or what or why anything is worth reading or not worth reading other than it gives you a certain kind of pleasure.

I don't think I'm answering your question. Give me the question again.

MC: The Guzmanns' hybridity.

JC: I don't think there's an answer to that. Because they are outside the norm. And his being outside the norm, being sort of an idiot, is part of the notion of the outsider, or the outlier, someone who's not within the culture, who's considered a kind of freak, a geek or a golem, or whatever. 
Ah, there's the little cat! Come to say hello! Animals are the same thing to me. I never had a pet-well I supposedly had a pet dog who hated me. My mother said she bought this dog for me but it was really her dog. Suddenly, at a very late age, I fell in love with cats.

MC: In the books, animals are like characters: Emily Dickinson ${ }^{22}$ has Carlo and Roosevelt ${ }^{23}$ has Fala.

JC: And in the most recent book which is coming out in October, the twelfth Isaac Sidel novel ${ }^{24}$, he picks up a stray cat at Riker's Island and the cat falls in love with him. Animals, again, what language do they have? You feel sympathy with them because they're mute in a way. What does it mean when she looks at me? I never know.

MC: We were talking about animals. The catfish in The Catfish Man also becomes a form of totem.

JC: A God of trickery from the Bronx River.

MC: Why the catfish?

JC: Because it's such a strange creature. I remember seeing the first catfish with whiskers. The word 'catfish' is such a strange word! A fish that looks like a cat, it's very powerful to a child. And seeing it come out of the water. Fish are strange enough, even when they rise out of the water. The frogs. The most magical thing I can remember is being a child and going through a stream with my brother in some place in the country and it was a tremendous adventure, we would cross, go through barbed wire to continue because the stream went from one piece of property to the next so we had to go across the barbed wire to continue. The stream is like the unconscious. I remember just taking this long adventure into the unknown. That was to me the most exciting thing that ever happened to me. I was with my brother, we were exploring. But the catfish is a totem. Animals are totems because they speak to us but we don't understand.

MC: Another prominent animal is the chicken. The geek swallows chickens, Bathseba cooks Chicken Kiev, Jerónimo looks at dead chickens in the street..

JC: Chickens. Well, chickens, first of all they're very stupid. In the summer, we would go to a farm where they had chicken coops.

MC: And you write in The Catfish Man that your brother worked there...

JC: Yes, he was filled with chicken feathers. The idea of seeing the farmer milk the cow was very-and also he was married at one point. He owned a whole farm but he lived in a room that was even smaller than a closet. He was very bizarre. He lived in a closet, in a coop!

MC: Now, a question about food and how it may be seen as a way to perceive the world. Some foods are clearly associated with childhood-charlotte russe, for instance, or even the catfish. Occasionally the question of digestion is also mentioned-in your graphic novel Family Man, Don Furioso suffers from constipation. You also have Isaac Sidel who has a tapeworm, which is really his instinct.

JC: Yes, his conscience in a way. He can have a dialogue with the worm but then the worm disappears. 
MC: Would you consider the digestive tract as a metaphor for one's relationship to the world?

JC: I would say that the feces are magical because your body produces it. For the child it's a kind of magic that you produce.

MC: But it's also what you reject, get rid of, some kind of garbage?

JC: Yes, but for the child, a wonder.

MC: Because, in On the Darkening Green ${ }^{25}$, with Boris the Wolfman, the retarded boy, in a cage, eating his excrements, you have those scenes which really seem to come straight out of the asylums described in Foucault's Madness and Civilization.

JC: Yes, that was a very important book for me, Foucault. I really loved his book. And many of the French philosophers, I mean the French-also Baudelaire was very important to me, Godard is very important as a filmmaker and Flaubert as a writer, and Beckett of course. The one writer that I can't read in English, I tried to read it in French, is Proust. It doesn't mean anything in English really, it's gibberish. So I had a tutor and we got through one or two pages and never got beyond that. The first opening sentences.

MC: Speaking about France, in Movieland you write "I was curious about what drew me to France. Some longing to return to that territory of my first alphabet books ${ }^{26}$ ?" Are you in search of your origins in France?

JC: I don't know. For example when I was in Junior High School, they offered two languages, French and Spanish, and almost everybody took Spanish because there was a practical use for it, but I didn't, I took French. We had a very small class.

MC: But it's also Europe, where your parents came from.

JC: It's Europe, the first time I came to Europe, I went first to Spain, I saw the balconies-and even the aroma. And also Rome, and Berlin. It's not only Paris. I could have lived in Barcelona. It was a way not only of going back to Europe, it was a way of vanishing to me, vanishing into a world where nobody else knew you. It was an act of disappearance. I fell in love with almost every city, even small cities I went to in France, and I also went to a lot of small cities in Italy because I would go to all those festivals, and some small cities in Germany, and also in Geneva. To me, Geneva was an ideal place because it had both the lake and mountains. It had this old town. In another lifetime I probably would live in Geneva because I could take this little boat and go across the lake and I could see the mountains. Mountains are very important to me. As a kid, that's where you imagined God was, in the mountains.

MC: In terms of writing, Beckett wrote in French, which was not his first language. You had to learn French. In a way you became...

JC: Débile!

MC: .... beginner.

JC: Yes, I never really mastered it. I remember writing compositions for my tutor and it took me hours to just write a sentence. I began to wonder how anyone can master any language. Some people can just pick up eight or nine or ten languages, and I could barely master English! So I just didn't understand how. It was a great puzzle to me. But I did write a few letters in French and I knew the grammar, I had this big dictionary. I don't know, but somehow France represents something to me that I'm not even conscious of. I don't really know. It represents the other, that which is exotic, and also safety in some sense. I wouldn't be able to articulate it. 
MC: I have a question about snow. You seem to have inherited this motif from The Pedersen Kid by Gass.

JC: Which I love, my favorite piece of work.

MC: The Secret Life of Emily Dickinson almost starts in the snow, with the deer that is rescued by Tom. How meaningful is snow for you? Is it akin to the enigma in Melville's work?

JC: The whiteness, the white whale. What I love about that piece, The Pedersen Kid, is that in the end Gass is questioning the fact that we exist at all, that human existence is just not real, it's a phantom. So to me, it was a very, very powerful work because this work of the baby found, a frozen child, it's like a tar baby. It's the same thing, this magical-or a golem! The baby found frozen in the snow is a kind of golem. But does the baby really exist, what does the snow suggest, are people coming to kill them? We don't know, we don't know anything. We're locked into a world that's disappearing, just as language arrives and disappears in the same instant.

MC: In the archives at the Fales Library ${ }^{27}$, I noticed you did some research on idiot savants and as well as on people with progeria.

JC: Yes, progeria does exist in Pinocchio's Nose.

MC: The idiot savant is perhaps a type of genius because there is this specific streak of acute intelligence.

JC: The idiot savant is very important because the idiot savant has a very, very specific memory and that memory is usually associated with numbers. The idiot savant can see a limited view of the world but that view is much clearer than ours. The artist is a kind of idiot savant because in order to have the clarity to put something together, you have to block out everything else, it's not so different.

MC: But, for you, are the idiot savants' numbers also a form of expression? Their memory can't really be seen as a work of art, or can it?

JC: It's not like a work of art but they are works of art. It's not what they do or what they say, somehow it's the magic. Art is magic to me. And that's why, to me, forgive me for saying it, most writers are unreadable because they don't have that magic. For example, the first time I looked at Lolita and I saw the sentence "Lo-lee-ta, three trips of the tongue," I knew I was going to love the book because this was someone who had the gift of music. But very few writers have it and most books that you read are about everyday life, and I'm not interested in that. It doesn't mean anything to me.

MC: Let's come back to the character Paul Morphy, who is also a real, historical person, a brilliant chess player. What drew you to him?

JC: I was an avid chess player for a while. I had no gift whatsoever but I used to go to the Marshall Club, which was where Bobby Fisher played, it was in Greenwich Village. I would sit and you could always have a game. I became fascinated. And I had an editor who played chess, one of the most important editors. We would play a game of chess by mail. I would do a move, he would do a move, and I had a chessboard that was set up. So chess is a trap, it's a language trap. There's no victory in a chess game. Maybe you get out of the maze, but the maze is there to trap you. I see chess or any kind of game as a kind of entrapment. But Paul Morphy, to me, was very interesting because first of all he became insane, and second of all, I think he grew up in New Orleans, and if I remember right, because it was a long time ago, he dressed in women's clothes, he was a crossdresser. And he played chess by instinct, the way Bobby Fischer played. That's why Bobby Fisher at his best was unbeatable because his 
moves didn't make any sense. When he played his world championship, he was playing against ten players and he beat them all because they didn't understand. His moves made no sense, and they couldn't find the sense of his game. So, I would suspect that Morphy had the same genius. You can't beat someone when you don't understand the rationality of their movement.

MC: There are a number of children in your works-Marianna Storm, Alyosha, Margaret Tolstoy when she's young-who are defenseless, vulnerable, but also extremely creative.

JC: They're creative and they pretend to be adults. Most often they're women. For Margaret Tolstoy, the first scene of The Good Policeman ${ }^{28}$ opens up in Paris when she's a child. It was very hard to write that scene. I had just been to the cemetary Montparnasse. Alyakhine, the Russian German chess champion, is buried there. I think that children have a certain magical power and they lose it as they become adults. They have a vision of the world that they will no longer have when they become adults. Their creativity is impaired, it seems to me.

MC: But in El Bronx ${ }^{29}$, Alyosha goes to the Merlin School, which is another version of the Voice Project at Stanford?

JC: Yes, it was an idea which I still believe in. The only way you can get rid of poverty is through education. I was very lucky because I was very poor and I was able to go to the best possible school where all we did was read books for four years. I had a classic education. Other people wanted to become doctors or lawyers, so they wanted to use this education to become something. And what did I do? First of all, I wasn't supposed to graduate because I hadn't finished the Science requirement, but I'd already been elected to Phi Beta Kappa, so in a way they couldn't not allow me to graduate. I was playing chess and I said, "No, I'm not taking this course." My mother had to go to school and speak to the deans and they finally let me-I didn't have to take the course. I was very lucky that I had this education, because having had it, you really didn't need anything else. There was nothing, once you've read through... I mean, we didn't read the Eastern philosophers, so there was something that was left out. But if you go back from the old Testament to the Greeks through the Middle Ages, St. Augustine, Molière, Rabelais, you have a grip, and Tolstoy, Dostoevsky, and you don't really need much else after that. Other people went on to law school and I worked as a parkie for the department of parks. It was a way of writing. I would sit in a little shed because you work from nine to five but what do you do until three, there are no school children until three, so you only have two hours where you really have to work. I would have stayed there for the rest of my life but I don't know, something happened. I had no ambition outside of wanting to learn the craft of writing and OK, maybe to teach yourself, to be your own master. Maybe it's a futile thing but I did it by reading Joyce, Nabokov, Saul Bellow...

MC: I found an article in the archives on finding the alpha state. In Sizzling Chops, you talk of the little white ball as a support for meditation.

JC: You can't play championship table tennis without being in an alpha state. It has to be an out-of-body experience. We had a club and I was on the worst team, we had eight teams and I was on the eighth, maybe the seventh. But I would always watch the matches of the very first team and you could see how they played. When they were playing, they were in a kind of alpha state because they were getting balls that no one else could get, that were impossible to get. You go for, to be in that kind of... I don't know, a sort of calm within the storm, how else to say. Because it's not enough 
to have the technique, I never had the technique, and yet I was able to beat players that were much better than I was, because I could get in into this alpha state; I didn't always win, many times I lost. Players were very surprised, because we would warm up and they would think, this guy can't play, and then they couldn't score a point! I just was in a different world.

\section{NOTES}

1. Charyn, Jerome. Eisenhower, My Eisenhower. New York: Holt, Rinehart and Winston, 1971.

2. Charyn, Jerome. Blue Eyes. New York: Simon \& Schuster, 1975.

3. Charyn, Jerome. Sergeant Salinger. A Novel. New York: Bellevue Literary Press, 2021.

4. Charyn, Jerome. New York Cannibals. Ill. François Boucq. Paris : Éditions du Lombard (Signé), 2020.

5. Charyn, Jerome. Jerzy. A Novel. New York: Bellevue Literary Press, 2017.

6. Kosinsky, Jerzy. The Painted Bird. New York: Houghton Mifflin, 1965.

7. Charyn, Jerome. Pinocchio's Nose. New York: Arbor House, 1983.

8. Tuten, Frederic. «A Conversation With Jerome Charyn ». Ed. Sophie Vallas. Conversations With Jerome Charyn. Jackson: University Press of Mississippi, 2014 (9).

9. Charyn, Jerome. The Man Who Grew Younger and Other Stories. New York: Harper \& Row, 1963.

10. Charyn, Jerome. "Jerome Charyn". Ed. Dedria Dryfonski. Contemporary Authors Autobiography Series. Vol. I. Detroit: Gale Research Company, 1984 (179).

11. Charyn, Jerome. Darlin' Bill. A Love Story of the Wild West. New York: Arbor House, 1980.

12. Charyn, Jerome. The Catfish Man. A Conjured Life. New York: Arbor House, 1980.

13. Charyn, Jerome. Le Croc du serpent. Ill. José Muñoz. Paris: Casterman, 1997.

14. Charyn, Jerome. Joe DiMaggio. The Long Vigil. New Haven: Yale University Press, 2011.

15. Charyn, Jerome. The Seventh Babe. New York: Arbor House, 1979.

16. Charyn, Jerome. Sizzling Chops \& Devilish Spins. Ping-Pong and the Art of Staying Alive. New York: Four Walls, Eight Windows, 2001.

17. Golding, Edmund. Nightmare Alley, 1947.

18. Kazan, Elia. Viva Zapata!, 1952.

19. Charyn, Jerome. Family Man. Ill. Joe Staton. San Diego: IDW Publishing, 2019 [New York: Paradox Press, 1995].

20. Charyn, Jerome. The Education of Patrick Silver. New York: Arbor House, 1976.

21. Charyn, Jerome. Blue Eyes. New York: Simon \& Schuster, 1975.

22. Charyn, Jerome. The Secret Life of Emily Dickinson. A Novel. New York: Norton, 2010.

23. Charyn, Jerome. The Franklin Scare. New York: Arbor House, 1977.

24. Charyn, Jerome. Winter Warning. An Isaac Sidel Novel. New York: Pegasus Crime, 2017.

25. Charyn, Jerome. On the Darkening Green. New York: McGraw-Hill, 1965.

26. Charyn, Jerome. Movieland. Hollywood and the Great American Dream Culture. New York: Putnam, 1989 (143).

27. "The Jerome Charyn Papers." Fales Library. New York University.

28. Charyn, Jerome. The Good Policeman. London: Blooomsbury, 1990.

29. Charyn, Jerome. El Bronx. New York: Warner Books, 1997. 


\section{AUTHOR}

\section{MICHAËLA COGAN}

Université de Franche-Comté 